\title{
SMART FARMING IN AGRICULTURAL INDUSTRY: MOBILE TECHNOLOGY PERSPECTIVE
}

\author{
Žarko Rađenovićl, Bojan Krstić2, Milan Marković3 \\ *Corresponding author E-mail: bojan.krstic@eknfak.ni.ac.rs
}

A R T I C L E I N F O
Original Article
Received: 29 February 2020
Accepted: 25 July 2020
doi: 10.5937/ekoPolj2003925R
UDC 338.43:621.39

Keywords:

smart farming, agricultural industry, mobile technology, agricultural information systems, neural networks

JEL: Q16, C45, C67

\begin{abstract}
A B S T R A C T
The aim of this research is to examine key indicators that are necessary for the implementation and development of smart farming concepts in the agricultural industry, especially from the applied mobile technology point of view. Accordingly, the authors used a neural network based software solution to determine the correlation, relationship structure and partial contribution of indicators for the mobile technology development in agricultural industries in selected countries. The validity of the input-output model in a neural network based software solution was evaluated using the Minkowski error and Quasi-Newton method through several iterations/epochs. The neural network structure has shown the importance of particular indicators for adopting a mobile technology perspective in the agricultural industry, where the application of Information and Communications Technologies (ICT) in agriculture is most emphasized. Only those countries that invest the most in the ICT in the agricultural sector can achieve greater efficiency and productivity by applying smart farming.
\end{abstract}

(C) 2020 EA. All rights reserved.

\section{Introduction}

Agriculture is one of the most important sectors in the world in the context of rapidly increasing population. "Technological progress in this field that needs control and optimization can really contribute to save environmental resources, respect business and international laws, satisfy the consumer needs, and pursue economic profits" (Balducci et al., 2018). One of the biggest challenges in agriculture is to improve food quality

1 Žarko Rađenović, Ph.D., Research Assistant, Innovation Centre of the University of Niš, Univerzitetski trg 2, 18000 Niš, Phone: +381 638787 359, E-mail: zarkoradjenovic@ hotmail.com, ORCID ID (https://orcid.org/0000-0002-3679-7870)

2 Bojan Krstić, Ph.D., Full professor, Faculty of Economics, University of Niš, Trg kralja Aleksandra Ujedinitelja 11, 18000 Niš, Phone: +381 18528 685, E-mail: bojan.krstic@ eknfak.ni.ac.rs, ORCID ID (https://orcid.org/0000-0003-4597-6819)

3 Milan Marković, Ph.D., Research Associate, Innovation Centre of the University of Niš, Univerzitetski trg 2, 18000 Niš, Phone: +381 642885 134, E-mail: markovicmilan89@, gmail.com, ORCID ID (https://orcid.org/0000-0002-9617-6697) 
and increase productivity without unnecessary and redundant manual work. Mobile technology certainly enables efficient use of inputs and reduces the demand for labour, leading to increased production productivity (Mykulskyi, 2019). The major challenge for hi-tech agriculture is to ensure that new technologies help farmers become more economically competitive (Jurjević et al., 2019).

In order to achieve this, it is necessary to have information-intensive and precise farming techniques based on knowledge (Milovanović, 2014). This involves constant and effective monitoring as well as making agriculture smart using automation and Internet of Things (IoT) technologies that are "personalized" in mobile technologies (Gondchawar, Kawitkar, 2016). "Monitoring contains modules like remainder, plant growth monitoring in various stages, irrigation planner, crop profit calculator, calamity check and problem identifier" (Mohanraj et al., 2016). According to the agricultural areas the prediction data varies and it is provided to the farmers so that they can plan for their farming (Savitha, UmaMaheshwari, 2018).

Certainly, the usage of Information and Communication Technologies (ICT) brings relevant information to farmers in real time (Mahant et al., 2012). In order to improve efficiency, productivity, global market and reduce human intervention, time and cost there is a need to divert towards new technology in agriculture based on artificial neural networks algorithms and mobile technology, for example crop prediction using smartphones (Jha et al., 2019). The data is stored on the web server which can then be visible to the farmer on the web browser and on the mobile phone too (Pawar et al., 2018). Therefore, it is necessary to implement the digitalization of agriculture and the automation of agricultural techniques, and to collect and analyse farm data (Ashifuddin, Rehena, 2018) using the concept of internet based smart farming (Charania, Li, 2019).

This agricultural data is processed and analysed into mobile applications that are suitable for automated real-time detection of farm conditions (Ferentinos, 2018). More and more data are being generated in agriculture and the rest of the food chain, which helps steer production processes with greater precision (Poppe et al., 2013). General crop, pest, disease, soil and irrigation and weed management and also yield prediction are key areas where mobile technology and artificial intelligence through neural networks should be deployed (Bannerjee et al. 2018). This neural network system in agriculture as an integral part of applied machine learning in disease detection, for example "is based on a self-organizing map neural network and data fusion of hyperspectral reflection and multi-spectral fluorescence imaging" (Liakos et al., 2018).

Consequently, it is clear that smartphones and external sensors show fascinating new opportunities for farmers in the digital age (Daum et al., 2018). One of the main priorities of the European Union are innovation and smart development (Wasilewski, \& Wasilewska, 2019). Internet-based remote control farming activities followed by mobile technology and mentioned sensors could create a wireless farm network and this will be a significant contribution to the smart farming concept (Dursun, Ozden, 2011). Mobile technology with smartphones and other smart agri-devices extend conventional 
tools (rain gauge, tractor, notebook) by adding autonomous context-awareness to all kinds of sensors, built-in intelligence, capable of executing autonomous actions or doing this remotely (Wolfert et al., 2017).

Mobile technology with application support for smart devices enables the wireless connection and communication of multiple agricultural machines and devices simultaneously, which ultimately leads to the development of a machine-to-machine concept. This concept involves the independent communication of agricultural machines regarding the data exchange of the agricultural parameters values such as elevation, mean daily temperature, max. daily temperature, min. daily temperature, wind speed, relative humidity, sunshine hours, daylight hours, latitude, condition coefficient. In this way, mobile technology performs the function of monitoring, collecting and analysing data of the state of the plant and animal life on the farm, current production, weather and soil conditions. Thus, mobile technology through its applications also influences the implementation of the big data concept and cloud computing in agriculture.

Also, mobile technology based on IoT concept "assisted agriculture research patterns to incorporate network platforms, the architecture of the respective network, applications, security issues, and challenges among others" (Mahbub, 2020). All of this means that "the evolution of agriculture steps into Agriculture 4.0, thanks to the employment of current technologies such as IoT, Big Data, Artificial Intelligence, Cloud Computing and Remote Sensing" (Zhai et al., 2020), which especially thanks to mobile technology implementation. This technology makes farm more intelligent and makes it possible to create a smart farm concept (Suakanto et al., 2016). Figure 1 shows the share of smart concepts in the world.

Figure 1. Percentage share and global contribution of smart agriculture in world regions

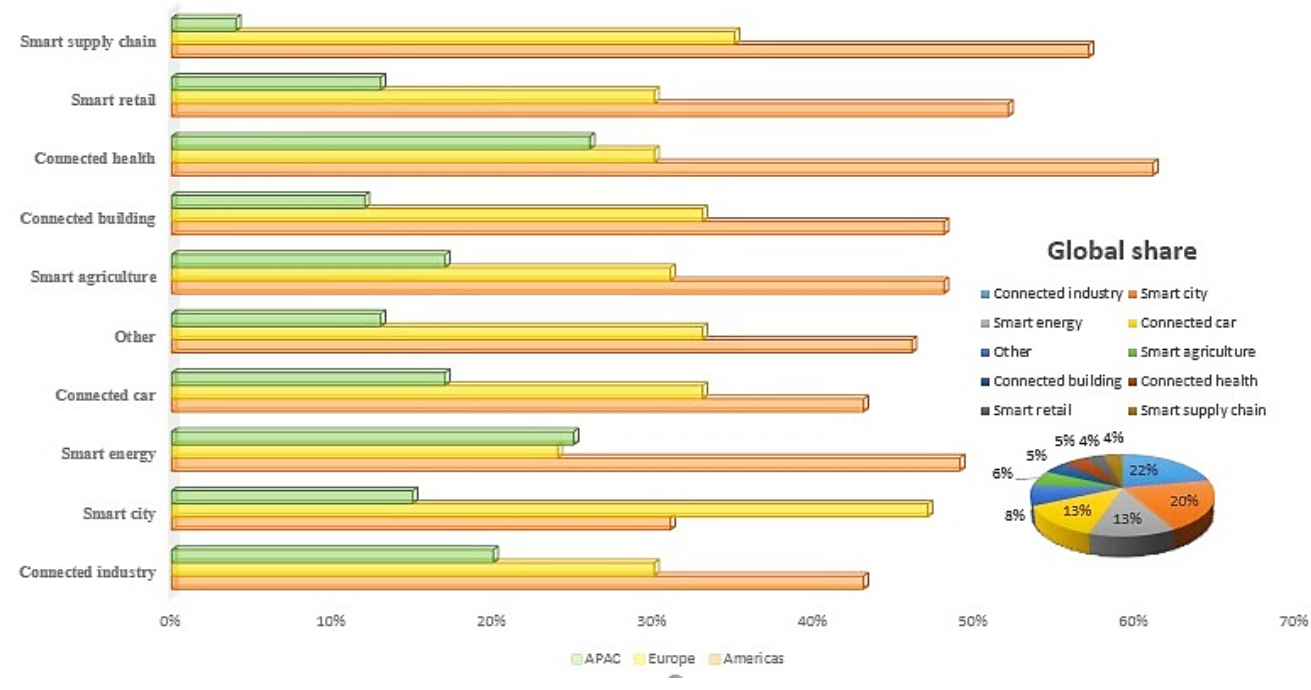

Source: Authors' calculation based on IoT Analytics 2016 Global Overview 


\section{Materials and methods}

The methodology used in this paper is based on a software solution for neural networks, which aims to discover the connection between inputs and output as a target variable in the example of a smart farming concept and its mobile technology perspective. In agricultural industry "neural network applications have gained popularity due to their functional characteristics, lesser data requirement and capability of long term forecasting which provide many advantages over traditional analytical approaches" (Nema et al., 2017).

For this purpose, the Neural Designer - Machine Learning Software solution was used to form the optimal neural network architecture for selected mobile technology indicators of smart farming because it takes some intelligence to interpret the agricultural data collected and analyse the data accordingly in order to predict the outputs, not the next traditional rule-based algorithm (Shekhar et al., 2017). The neural network method was applied to determine the highest correlation between the input variables and the output variable and to notice which indicator most influences the output variable structure, for those selected countries.

Namely, the research is based on selected countries, who have made some progress in smart farming technology application, especially in its mobile technology perspective. Accordingly, based on the available database for selected countries (Table 1), the authors selected seven indicators necessary for the implementation of the mobile technology concept, which were taken as inputs/output variables:

- Agriculture value added percentage of GDP (input) - the value of this indicator shows the agricultural value added percentage contribution to GDP.

- Mobile phone subscriptions/100 habitants (input) - the value of this indicator shows the mobile phone availability at the farmers, especially the number of mobile phones on 100 habitants.

- Farmers using Internet/100 habitants (input) - the value of this indicator is based on the number of farmers who have used Internet on 100 habitants.

- Mobile broadband subscriptions/100 habitants (input) - the value of this indicator shows the density, actually the mobile technology broadband access on 100 habitants.

- Governance Agriculture Online Service Index (input) - this indicator shows the value of digital services providing by state authority which in charge of agriculture. Digital services refer to providing consulting advices such as statistical analysis and applicative support for some agricultural sectors. The value of this index is better if it is close to 1 .

- Importance of ICT in Agriculture (input) - the value of this index relates to determining the importance of the application of ICT in agriculture and ranges from 0 to 5 . 
- WEF Network Readiness Index (output) - this indicator represents the index of the World Economic Forum (WEF) which defines the country's readiness to accept the digitalization and smart farming concept in agriculture. The value of this index is better if it is close to 5 .

Table 1. Smart farming indicator values for the selected countries

\begin{tabular}{|c|c|c|c|c|c|c|c|}
\hline Countries & $\begin{array}{c}\text { Agriculture } \\
\text { value added } \\
\text { (\% of GDP) }\end{array}$ & $\begin{array}{c}\text { Mobile phone } \\
\text { subscriptions } \\
\text { /100 habitants }\end{array}$ & $\begin{array}{c}\text { Farmers } \\
\text { using } \\
\text { Internet/100 } \\
\text { habitants }\end{array}$ & $\begin{array}{c}\text { Mobile } \\
\text { broadband } \\
\text { subscriptions } \\
\text { /100 habitants }\end{array}$ & $\begin{array}{c}\text { Governan- } \\
\text { ce } \\
\text { Agriculture } \\
\text { Online } \\
\text { Service } \\
\text { Index }\end{array}$ & $\begin{array}{c}\text { Importance } \\
\text { of ICT in } \\
\text { Agriculture }\end{array}$ & $\begin{array}{c}\text { WEF } \\
\text { Network } \\
\text { Readine-ss } \\
\text { Index }\end{array}$ \\
\hline Armenia & 21.93 & 112.40 & 46.30 & 31.00 & 0.61 & 4.22 & 4.24 \\
\hline Azerbaijan & 5.69 & 107.60 & 58.70 & 43.90 & 0.43 & 5.23 & 4.28 \\
\hline Belarus & 8.86 & 118.80 & 54.20 & 45.90 & 0.32 & 0.00 & 0.00 \\
\hline $\begin{array}{c}\text { Bosnia and } \\
\text { Herzegovina }\end{array}$ & 7.51 & 91.20 & 67.90 & 22.20 & 0.37 & 3.74 & 3.98 \\
\hline Georgia & 9.20 & 115.00 & 43.10 & 16.40 & 0.59 & 3.95 & 4.22 \\
\hline Hungary & 4.37 & 116.40 & 72.60 & 26.30 & 0.55 & 3.55 & 4.33 \\
\hline Kyrgyzstan & 17.25 & 121.40 & 23.40 & 22.70 & 0.27 & 2.70 & 3.53 \\
\hline $\begin{array}{c}\text { North } \\
\text { Macedonia }\end{array}$ & 10.23 & 106.20 & 61.20 & 38.30 & 0.24 & 4.88 & 4.41 \\
\hline Moldova & 15.23 & 106.00 & 48.80 & 47.20 & 0.52 & 3.67 & 4.03 \\
\hline Romania & 5.36 & 105.60 & 49.80 & 37.60 & 0.44 & 3.43 & 4.15 \\
\hline Russia & 3.95 & 152.80 & 61.40 & 60.10 & 0.70 & 3.82 & 4.52 \\
\hline Serbia & 9.68 & 119.40 & 51.50 & 54.80 & 0.39 & 3.22 & 3.95 \\
\hline Slovakia & 3.74 & 113.90 & 77.90 & 53.60 & 0.48 & 3.29 & 4.23 \\
\hline Slovenia & 2.15 & 110.20 & 72.70 & 41.80 & 0.42 & 3.42 & 4.64 \\
\hline Tajikistan & 27.40 & 91.80 & 16.00 & 0.10 & 0.06 & 3.92 & 3.20 \\
\hline Turkey & 8.03 & 93.00 & 46.20 & 32.30 & 0.55 & 4.21 & 4.41 \\
\hline Ukraine & 11.78 & 138.10 & 41.70 & 5.40 & 0.26 & 2.69 & 4.00 \\
\hline Uzbekistan & 18.98 & 74.30 & 38.20 & 1.10 & 0.44 & 0.00 & 0.00 \\
\hline
\end{tabular}

Source: Authors' calculation based on FAO, 2018

Below the text is a circle chart (Figure 2) that aims to indicate fluctuations in the values of the analysed indicators for smart farming mobile technology concept by country. The $x$ axis of this graph shows the values and the names of the indicator by column, while the $y$ axis shows the name of the country to which the particular indicator refers. The circle chart for each indicator also shows the minimum and maximum values of each indicator by country. 
Figure 2. Circle chart of the selected indicator values

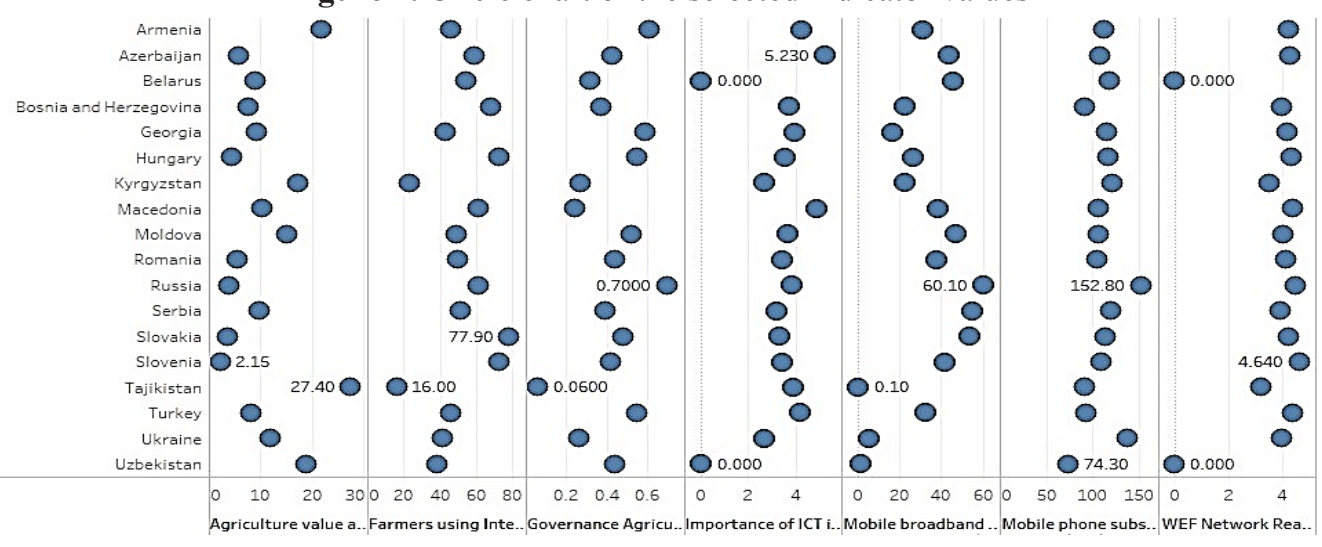

Source: Authors' calculation

\section{Results and Discussions}

In the Neural Designer software solution, an analysis of the inter-correlation of input variables was first conducted to determine which variables have the highest degree of correlation. Thus, from Table 2 it can be concluded that the highest degree of correlation exists between Farmers using Internet/100 habitants and Mobile broadband subscriptions/100 habitants. The value of this correlation coefficient is 0.67 which at the same time indicates the joint contribution of the mentioned input variables in the formation of the output variable. Their positive relationship also indicates an identical course of action when it comes to the formation of the output variable of the WEF Network Readiness Index. On the other hand, the highest negative correlation, which is -0.88, has variables the Agriculture value added percentage of GDP and Farmers using Internet/100 habitants, which means that these variables have a diametrically opposite effect on the output variable and are not dependent on each other.

Table 2. Correlations between agricultural mobile technology indicators

\begin{tabular}{|c|c|c|c|c|c|c|}
\hline & $\begin{array}{l}\text { Agricultu-re } \\
\text { value added } \\
(\% \text { of GDP) }\end{array}$ & $\begin{array}{c}\text { Mobile phone } \\
\text { subscripti- } \\
\text { ons } / 100 \\
\text { habitants }\end{array}$ & $\begin{array}{c}\text { Farmers } \\
\text { using } \\
\text { Internet } / 100 \\
\text { habitants }\end{array}$ & $\begin{array}{l}\text { Mobile broadband } \\
\text { subscripti-ons/100 } \\
\text { habitants }\end{array}$ & $\begin{array}{c}\text { Governance } \\
\text { Agriculture } \\
\text { Online } \\
\text { Service Index }\end{array}$ & $\begin{array}{l}\text { Importance } \\
\text { of ICT in } \\
\text { Agricultu-re }\end{array}$ \\
\hline $\begin{array}{l}\text { Agricultu-re } \\
\text { value added } \\
(\% \text { of GDP })\end{array}$ & 1 & -0.45 & -0.88 & -0.74 & -0.65 & -0.28 \\
\hline $\begin{array}{r}\text { Mobi } \\
\text { subscription }\end{array}$ & $\begin{array}{l}\text { phone } \\
/ 100 \text { habitants }\end{array}$ & 1 & -0.12 & -0.21 & 0.29 & 0.16 \\
\hline \multicolumn{3}{|c|}{ Farmers using Internet/100 habitants } & 1 & 0.67 & 0.54 & 0.24 \\
\hline \multicolumn{4}{|c|}{ Mobile broadband subscriptions/100 habitants } & 1 & 0.51 & 0.41 \\
\hline \multicolumn{5}{|c|}{ Governance Agriculture Online Service Index } & 1 & 0.11 \\
\hline \multicolumn{6}{|c|}{ Importance of ICT in Agriculture } & 1 \\
\hline
\end{tabular}

Source: Authors' calculation 
Authors have considered that might be interesting to look for dependencies between single input and single target (output) indicator. This task calculates the values of the correlation coefficient between all inputs and target indicator (Figure 3). Correlation close to 1 means that a single target is correlated with a single input. On the other hand, correlation close to 0 means that there is not a relationship between an input and a target variable. Note that, in general, the target depends on many inputs simultaneously. Figure 3 shows that indicator Importance of ICT in Agriculture has the highest coefficient of correlation with WEF Network Readiness Index (0.890). It can be concluded that farmers which understand the importance of using ICT in agriculture are more likely to adopt a mobile technology perspective as a part of smart farming concept. In addition, this conclusion is also reflected in the neural network architecture (Figure 6).

Also, the lowest value of the indicator which represents Agricultural value added percentage of GDP (-0.59) means that there is no relationship between smart farming and its mobile technology perspective in increase GDP. This means that some countries don't implement smart farming concept in the appropriate agricultural areas and because of that wrong digitalization policy in agriculture sometimes there is no agricultural additional value.

Figure 3. Correlation coefficient values between all inputs and output

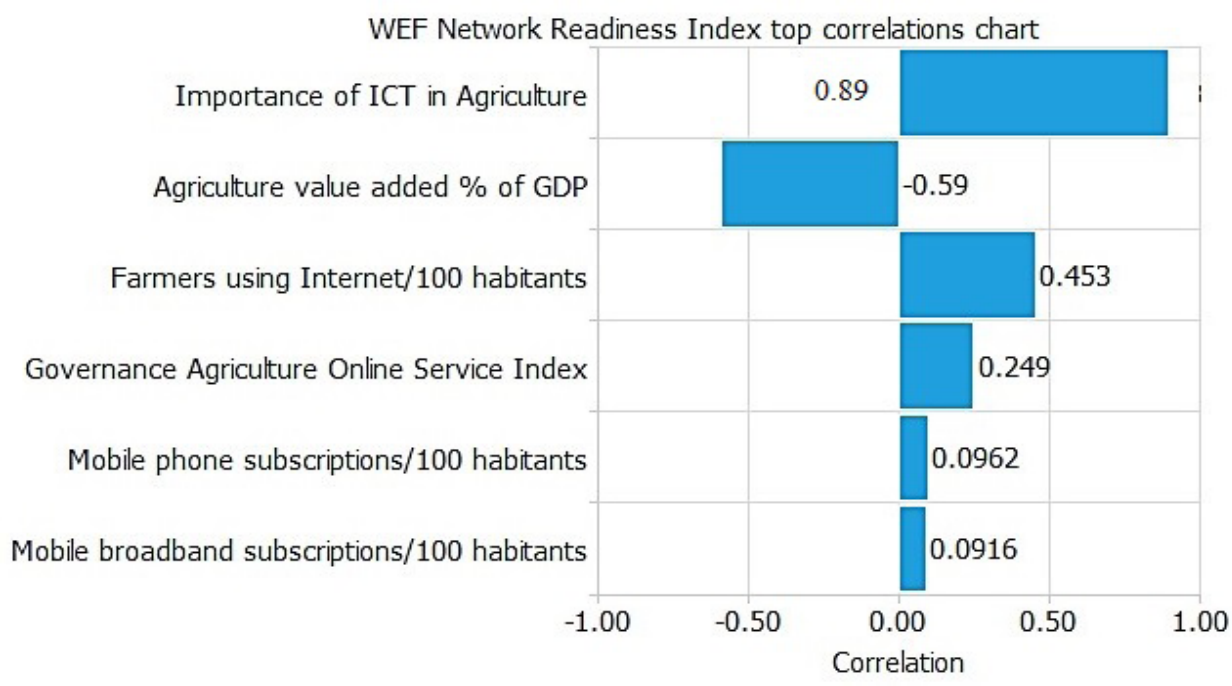

Source: Authors' calculation

It is very useful to see how the outputs vary as a function of a single input, when all the others are fixed. This can be seen as the cut of the neural network model along some input direction and through some reference point (Figure 4). The next plot shows the output WEF Network Readiness Index as a function of the input Farmers using Internet/100 habitants. The $x$ and $y$ axes are defined by the range of the variables Farmers using Internet/100 habitants and WEF Network Readiness Index, respectively. The grey point represents the reference point. 
Figure 4. Reference point for selected input and output

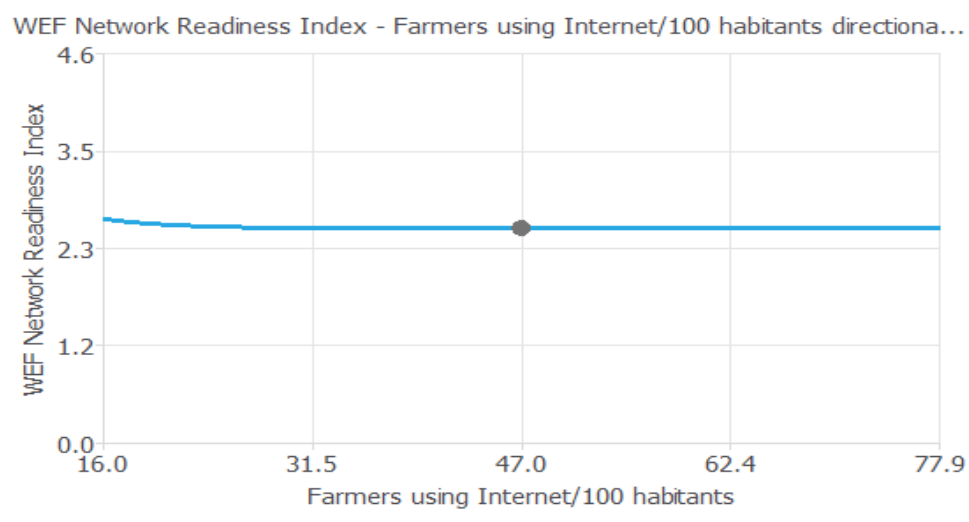

Source: Authors' calculation

For data collection an incremental order of selected indicators was used in the Neural Designer - Machine Learning Software. This software solution is based on a wide range of advanced neural network algorithms which can detect, identify relationships and predict trends between inputs and outputs in the form of applied mobile technology perspective. This incremental order method starts with a small number of neurons and increases the complexity until some stopping criteria is met. Also, input selection in this predictive model for smart farming is based on growing inputs method. This method calculates the correlation of every input with every output in the data set and creates neural network that only contains the most correlated input with the properly output.

The procedure used to carry out the learning process is called training or learning strategy. "The training strategy is applied to the neural network in order to obtain the best possible loss" (Neural Designer, 2020). The type of training is determined by how the parameters in the neural network are adjusted. The quasi-Newton method is used here for training. It is based on Newton's method, but does not require the calculation of second derivatives. Instead, the quasi-Newton method computes an approximation of the inverse Hessian at each iteration of the algorithm, by only using gradient information (Song, 2018). Figure 5 shows the training and selection errors in each iteration. The blue line represents the training error and the orange line represents the selection error. The initial value of the training error is 4.80926 , and the final value after 14 epochs is 0.00380483 . The initial value of the selection error is 1.08657 , and the final value after 14 epochs is 0.0180442 . 
Figure 5. Smart farming neural network model validation and correction through iterations/epochs

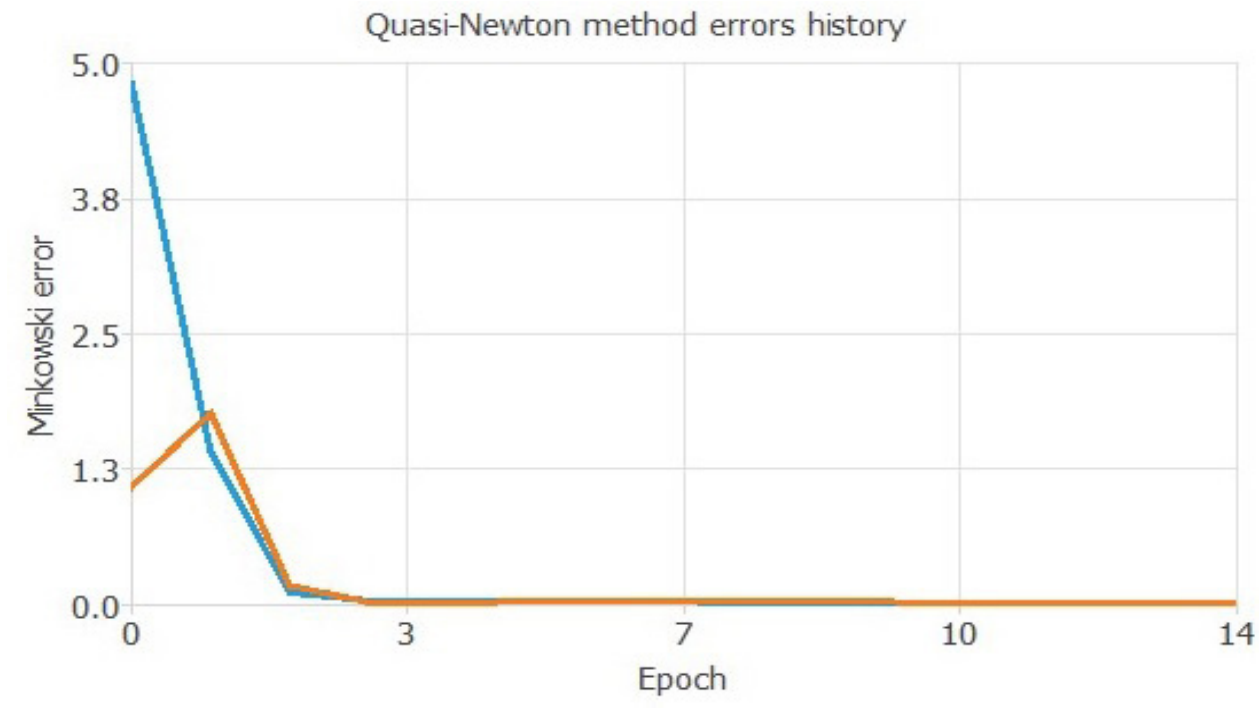

Source: Authors' calculation

The model validity is based on the so-called Minkowski error $(R)$, which referent value is 2 . In this model, Minkowski error is $1.2 \leq 1.3 \leq 2$ which confirmed model justification especially after fourteen epochs. Minkowski error can be expressed by this formula:

$$
E=\frac{1}{R} \sum_{n} \sum_{k=1}^{c}\left|y_{k}\left(x_{n} ; W\right)-t_{k n}\right|^{R}
$$

where $E$ is error function, $R$ is number $2, y_{k}$ is output layer, $x_{n}$ is input layer, $W$ is weights array, $t$ is time (Christiansen et al., 2014).

Finally, the graphical representation of the resulted deep architecture of the mobile technology smart farming indicators is shown in Figure 6. It contains a scaling layer, a neural network and an unscaling layer. The yellow circles represent scaling neurons, the blue circles perceptron neurons and the red circles unscaling neuron. The number of inputs is 6 , and the number of output is 1 . The complexity of the neural network architecture is 3 , represented by the numbers of hidden neurons. 
Figure 6. Neural network architecture for agricultural mobile technology indicators

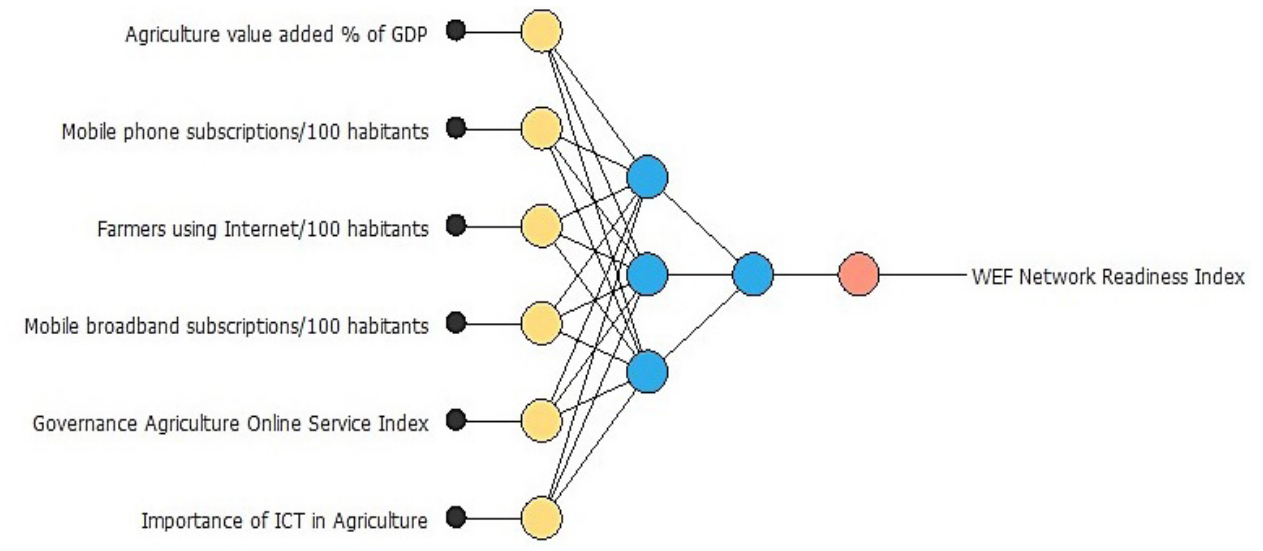

Source: Authors' calculation

The predictive model takes the form of a function of the output with respect to the five inputs. The mathematical expression represented by the neural network is written below:

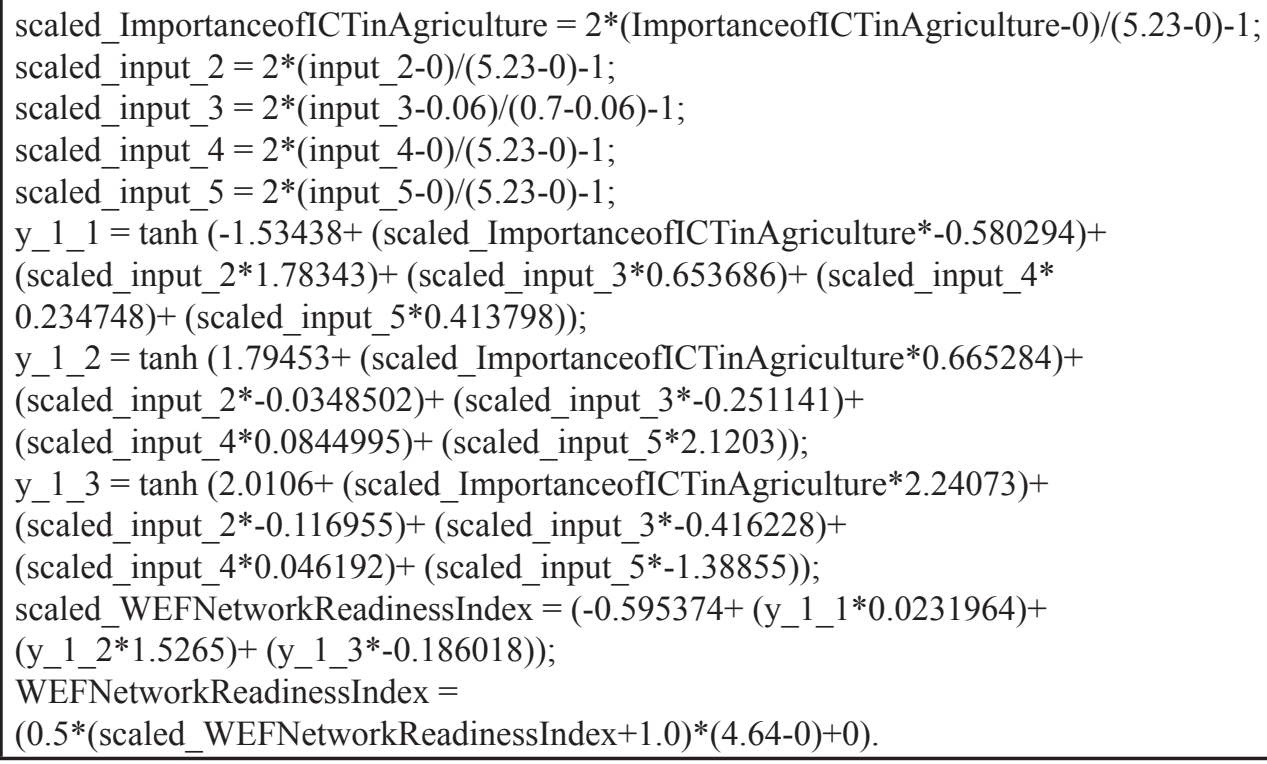

This expression takes the inputs: Agriculture value added percentage of GDP, Mobile phone subscriptions/100 habitants, Farmers using Internet/100 habitants, Mobile broadband subscriptions/100 habitants, Governance Agriculture Online Service Index, Importance of ICT in Agriculture and WEF Network Readiness Index as output. The future analysis may go toward solving regression issues through the scaling layer, the perceptron layers and the unscaling layer in feed forward fashion. 


\section{Conclusions}

The digitalization of agriculture is one of the most significant innovations in the agricultural sector. This process has led to a significant increase in value added in the production process and ultimately to an increase in the percentage share of the agricultural sector in GDP. The usage of mobile technology as an integral part of the digitalization process and the smart farming concept is certainly a basic factor in using ICT in agriculture. In order for mobile technology and its application support to experience full expansion, it is imperative that each country, or farm, shows a willingness to embrace digital innovations. By analysing the relationships of the variables, the importance of implementing ICT in agriculture has proven to be a key indicator of the country's willingness to embrace digitalization in agriculture. Namely, the country that has the highest index of applied ICT in agriculture can significantly increase the level of added value. This indicator had the greatest influence on output neural network structure, as can be seen in the analysis in the paper. The highest positive correlation was observed between Farmers indicators using Internet/100 habitants and Mobile broadband subscriptions/100 habitants, while the highest negative ratios are indicated by the Agriculture value added - \% of GDP and Farmers using the Internet/100 habitants indicators.

"Cost optimization techniques may be developed based on big data analytics that could be implied upon large scale agricultural sector" (Ray, 2017, p. 417) through mobile technology and its smartphones and other smart agri-devices as an integral part. This leads to the agricultural predictive analytics because the large amount of farm data could be processed. Specifically, mobile technology thus enables farmers to anticipate further farm production through applications and smartphones. Satellite imagery of farmland registering on smartphones with mobile technology reduces monitoring costs and gives a real-time view of the farm. This allows farmers to respond quickly to certain anomalies such as pest attacks on plant crops. In addition to practical application on the farm itself, mobile technology also reduces the administrative and operational costs.

\section{Acknowledgements}

The paper is a part of the research financed by the Ministry of Education, Science and Technological Development of the Republic of Serbia.

\section{Conflict of interests}

The authors declare no conflict of interest.

\section{References}

1. Ashifuddin Mondal, M., \& Rehena, Z. (2018). Iot based intelligent agriculture field monitoring system, In 8th International Conference on Cloud Computing, Data Science \& Engineering (Confluence), IEEE, Noida, India, 625-629. doi: https://doi. org/10.1109/CONFLUENCE.2018.8442535 
2. Balducci, F., Impedovo, D., \& Pirlo, G. (2018). Machine Learning Applications on Agricultural Datasets for Smart Farm Enhancement. Machines, 6(3), 1-22. doi: https://doi.org/10.3390/machines6030038

3. Bannerjee, G., Sarkar, U., Das, S., \& Ghosh, I. (2018). Artificial Intelligence in Agriculture: A Literature Survey. International Journal of Scientific Research in Computer Science Applications and Management Studies, 7(3), 1-6.

4. Charania, I., \& Li, X. (2019). Smart Farming: Agriculture's Shift from a Labor Intensive to Technology Native Industry. Internet of Things, 1-15. doi: https://doi. org/10.1016/j.iot.2019.100142

5. Christiansen, N.H., Voi, P.E.T., Winther, O., \& Høgsberg, J. (2014). Comparison of Neural Network Error Measures for Simulation of Slender Marine Structures. Journal of Applied Mathematics, 1-11. doi: https://doi.org/10.1155/2014/759834

6. Daum, T., Buchwald, H., Gerlicher, A., \& Birner, R. (2018). Smartphone apps as a new method to collect data on smallholder farming systems in the digital age: A case study from Zambia. Computers and electronics in agriculture, 153, 144-150. doi: https://doi.org/10.1016/j.compag.2018.08.017

7. Dursun, M., \& Ozden, S. (2011). A wireless application of drip irrigation automation supported by soil moisture sensors. Scientific Research and Essays, 6(7), 15731582. doi: https://doi.org/10.5897/SRE10.949

8. FAO (2018). Status of Implementation of e-Agriculture in Central and Eastern Europe and Central Asia - Insights from selected countries. Retrieved from http:// www.fao.org/3/I8303EN/i8303en.pdf (February 18, 2020)

9. Ferentinos, K.P. (2018). Deep learning models for plant disease detection and diagnosis. Computers and Electronics in Agriculture, 145, 311-318. doi: https:// doi.org/10.1016/j.compag.2018.01.009

10. Gondchawar, N., \& Kawitkar, R.S. (2016). IoT based smart agriculture. International Journal of Advanced Research in Computer and Communication Engineering, 5(6), 838-842. doi: https://doi.org/10.17148/IJARCCE.2016.56188

11. IoT Analytics 2016 Global Overview (2016). Retrieved from https://iot-analytics. com/global-overview-640-enterprise-iot-use-cases/ (February 17, 2020)

12. Jha, K., Doshi, A., Patel, P., \& Shah, M. (2019). A comprehensive review on automation in agriculture using artificial intelligence. Artificial Intelligence in Agriculture, 2, 1-12. doi: https://doi.org/10.1016/j.aiia.2019.05.004

13. Jurjević, Ž., Bogićević, I., Đokić, D., \& Matkovski, B. (2019). Information Technology as a Factor of Sustainable Development of Serbian Agriculture. Strategic management, 24(1), 41-46. doi: https://doi.org/10.5937/StraMan1901041J

14. Liakos, K.G., Busato, P., Moshou, D., Pearson, S., \& Bochtis, D. (2018). Machine Learning in Agriculture: A Review. Sensors, 18(8), 1-29. doi: https://doi. org/10.3390/s18082674

15. Mahant, M., Shukla, A., Dixit, S., \& Patel, D. (2012). Use of ICT in Agriculture. International Journal of Advanced Computer Research, 2, 2277-7970. 
16. Mahbub, M. (2020). A Smart Farming Concept Based on Smart Embedded Electronics, Internet of Things and Wireless Sensor Network. Internet of Things, 9, 1-30. doi: https://doi.org/10.1016/j.iot.2020.100161

17. Milovanović, S. (2014). The role and potential of information technology in agricultural improvement. Economics of Agriculture, 61(2), 471-485. doi: https:// doi.org/10.5937/ekoPolj1402471M

18. Mohanraj, I., Ashokumar, K., \& Naren, J. (2016). Field monitoring and automation using IOT in agriculture domain. Procedia Computer Science, 93, 931-939. doi: https://doi.org/10.1016/j.procs.2016.07.275

19. Mykulskyi, V. (2019). Branch Features of the Automated Accounting Organization at Agricultural Enterprise. Accounting and Finance, 4, 37-44.

20. Nema, M.K., Khare, D., \& Chandniha, S.K. (2017). Application of artificial intelligence to estimate the reference evapotranspiration in sub-humid Doon valley. Applied Water Science, 7(7), 3903-3910. doi: https://doi.org/10.1007/s13201-0170543-3

21. Neural Designer, Retrieved from https://www.neuraldesigner.com/learning/ tutorials/training-strategy (February 15, 2020)

22. Pawar, S.B., Rajput, P., \& Shaikh, A. (2018). Smart irrigation system using IOT and raspberry pi. International Research Journal of Engineering and Technology, 5(8), 1163-1166.

23. Poppe, K.J., Wolfert, S.,Verdouw, C., \& Verwaart, T. (2013). Information and communication technology as a driver for change in agri-food chains. EuroChoices, 12(1), 60-65. doi: https://doi.org/10.1111/1746-692X.12022

24. Ray, P.P. (2017). Internet of things for smart agriculture: Technologies, practices and future direction. Journal of Ambient Intelligence and Smart Environments, 9(4), 395-420. doi: https://doi.org/10.3233/AIS-170440

25. Savitha, M., \& UmaMaheshwari, O.P. (2018). Smart crop field irrigation in IOT architecture using sensors. International Journal of Advanced Research in Computer Science, 9(1), 302-306.

26. Shekhar, Y., Dagur, E., Mishra, S., \& Sankaranarayanan, S. (2017). Intelligent IoT based automated irrigation system. International Journal of Applied Engineering Research, 12(18), 7306-7320.

27. Song, H. (2018). Nature-Inspired VLSI Circuits - From Concept to Implementation. Lulu.com, USA.

28. Suakanto, S., Engel, V.J., Hutagalung, M., \& Angela, D. (2016). Sensor networks data acquisition and task management for decision support of smart farming. In 2016 International Conference on Information Technology Systems and Innovation (ICITSI), IEEE, 1-5. doi: https://doi.org/10.1109/ICITSI.2016.7858233

29. Wasilewski, A., \& Wasilewska, A. (2019). Financing the research and development activity for the agri-food sector and rural areas. Western Balkan Journal of Agricultural Economics and Rural Development, 1(1), 29-39. 
30. Wolfert, S., Ge, L., Verdouw, C., \& Bogaardt, M.J. (2017). Big Data in Smart Farming - a review. Agricultural Systems, 153, 69-80. doi: https://doi.org/10.1016/j. agsy.2017.01.023

31. Zhai, Z., Martinez, J.F., Beltran, V., \& Martinez, N.L. (2020). Decision support systems for agriculture 4.0: Survey and challenges. Computers and Electronics in Agriculture, 170. doi: https://doi.org/10.1016/j.compag.2020.105256 